Vida Davidaviciene,

Ph.D., Professor, Vilnius Gediminas Technical University, Lithuania

leva Meidute-Kavaliauskiene,

Ph.D., Associate Professor, Vilnius Gediminas Technical University, Lithuania

Regimantas Paliulis,

Vilnius Gediminas Technical University, Lithuania

\title{
RESEARCH ON THE INFLUENCE OF SOCIAL MEDIA ON GENERATION Y CONSUMER PURCHASE DECISIONS
}

Abstract. Members from different generations create challenges for marketing specialists due to their unique behaviour specifics and in the context of constant technology development, these challenges become only harder. In the current marketing situation, there is a new challenge - outreach and interest for generation $Y$ consumers. $A$ question arises - which means to apply and which of them would be effective. It is a new field of research both for scientists and marketing practitioners. The article analyses the members of generation $Y$ because in their case there are most prominent scientific discovery inquiries on their behaviour and marketing management decisions. By evaluating that, the aim of the article is to create a model of the influence of social media for generation $Y$ consumer purchase decisions. The need to offer a new model has appeared due to the changes in the current world that are changing the habits and features of the society, constantly improving technologies are changing the lifestyle, values and needs of people. The marketing decisions that were applied before are not presenting the desired results in the current market. Previous research allows identifying the specifics of generation $Y$, however, due to constantly changing technology environment it is not clearly known how this generation makes the decisions to purchase something. When wishing to find the right way to sell products and services to this generation, it is necessary to understand it and to find ways to communicate with it. When creating social media content and creating added value to the customers, it is vital to understand the complexity of the external and internal factors that determine their choice to buy. To achieve the goal of this article, the theoretical part presents a complex analysis of factors that determine consumer behaviour in social media, applications of generation theory for making marketing decisions; characteristics of generation $Y$ were identified. In this research, marketing factors that influence the consumer's decision to buy were analysed, their effects and application in the purchase process of generation $Y$ consumers were evaluated.

Keywords: electronic marketing, e-marketing, marketing, model, social media, technologies.

Introduction. Members from different generations create challenges for marketing specialists due to their unique features. A new problem arises as it is not completely clear how to reach generation $Y$ consumers. Therefore, both scientists and practitioners are searching for innovative ways and new marketing strategies are being created to attract generation $Y$ consumer attention (Valentine and Powers, 2013; Raudeliuniene and Davidavicius, 2017; Davidaviciene et al., 2017; Davidaviciene et al., 2019a). This generation is becoming mature and the purchasing power of the individuals is becoming stronger. The influence of the people around them, the experience and knowledge that is passed onto them affects their decisions to buy (Alavijeh et al., 2018). Previous research (Deloitte, 2015; Nash, 2018; Davidaviciene et al., 2019b) allows identifying the specifics of generation $Y$, however, due to rapidly changing technological environment, it is not clearly known how this generation makes a decision to purchase. Hoping to find a suitable way to sell products and services to this generation, it is vital to understand and find ways to communicate with it. More and more business subjects are discovering the importance of social media in the process of sales. Also, it is important to pay attention to the fact that product or service sales are greatly impacted by information communicated in social media. Deloitte (2015) claims that in the near future $100 \%$ of consumers will be constantly connected online with social media. Currently, social media and communicating via the Internet affects both online and in-store sales. Therefore, it is extremely important to integrate social media in the sales processes in a timely manner and to utilize the value that

Cite as: Davidaviciene, V., Meidute-Kavaliauskiene, I. \& Paliulis, R. (2019). Research on the Influence of Social Media on Generation Y Consumer Purchase Decisions. Marketing and Management of Innovations, 4, 39-49. http://doi.org/10.21272/mmi.2019.4-04 
it creates.

Companies operating in a global market are realising the value that social media creates. It would be possible to communicate more effectively about the products and services of a company by properly integrating the opportunities of social media as a marketing tool. It is vital to understand the complexity of extrinsic and intrinsic factors influencing their decision to buy (Nash, 2018). Therefore, it becomes important to understand generation $Y$ as consumers, that there would be conclusions formulated for making scientifically based decisions.

The research object of the article is generation Y's process of deciding to purchase within social media. The aim of the article - to create a model of social media influence for generation $Y$ consumer purchase decisions. A comparative scientific literature analysis and synthesis, generation $Y$ consumer survey, comparative analysis of statistic data have been performed and a model based on a case analysis has been created to reach the aim of the article.

Literature Review. As research shows, consumer behaviour is influenced by subjects such as lifestyle (Adnan et al., 2017), cultural differences and the place of residence (Zhong et al., 2018), opinion and experience of those around them (Jain et al., 2018), individual's hobbies and free-time activities (Silveira et al., 2018), emotions, experiences and other psychological motives, external factors (Kemp et al., 2018) and many more. Consumer decision-making process is complex and complicated as during it the individuals are affected by intrinsic and extrinsic factors (Nash, 2018). Generation theory is one of the ways allowing to identify a wide spectrum of these subjects that influences an individual decision. Each generation grows up having unique experiences, which makes them different. Augustin (2013) classifies the generations as follows:

- Silent generation - 1933-1945;

- Baby boom generation - 1946-1964;

- Generation X-1965-1980;

- Generation Y-1981-2000;

- Generation Z - from 2000.

So, generation $Y$ is the largest generation in history, and it's reaching its main period of work and making expenses by currently becoming mature. In the coming years, it's effect on the economy is going to be huge (Bolton et al., 2013). Generation Y lives in a rapidly developing environment. As they were growing up, the point of view changed towards women employment, respect has developed for racial and cultural differences (Williams and Page, 2011). It is a generation raised in a technological, social and wireless society where computers are in almost every home and educational institution.

In everyday endeavours, members of generation $Y$ are trustworthy, more tolerant and better travelled than most of generation X. Members of this generation live longer with their parents and have a close relationship with them. Generation $Y$ starts their own families and has offspring later on than the members of previous generations (Bolton et al., 2013). Generation Y agrees to work for a lower wage if the workplace offers more flexible working hours (Kane, 2017). It supports socially responsible companies and purchase products by paying attention to the image of the company. The main feature of generation $Y$ is a common and early relationship with the newest technology. This relation has changed the cognitive, emotional and social aspects of the generation. The main reason why the members of generation $Y$ use social media is interpersonal communication. The members of this generation value other people's opinion in the social space, on the Internet. Opinions regarding products and services that they use or are planning to use is very important for generation $Y$ (Bolton et al., 2013). They are interactive and impatient as they grew up in the society of technologies and instant gratification. They strive to blend in and be accepted by others. Because of this reason, social networks are a great environment to stay connected and express their personalities. Sending e-mails is not as interactive. Generation $Y$ is more likely to communicate via instant messaging platforms, such as «Facebook» or «Twitter», mobile apps, etc. Traditional media and 
advertisements have a very low impact on forming the opinion of this generation. Generation $Y$ grew up in a world overcrowded with media and brand names, which also took a toll on forming resistance towards direct advertising. Many companies understand this phenomenon and invest into the image of the brand, they try to create a certain identity and distinguish themselves from the other players in the market (Valentine et al., 2013; Raudeliuniene and Davidavicius, 2017; Raudeliuniene et al., 2018). More often it is emphasized that social media is one of the main environments to reach generation $Y$ consumers. Kemp (2018) claims that more than half of the people on Earth are constantly connected to a virtual network and that social networks have become an important part when creating marketing and sales strategies.

Kaplan and Haenlein (2010) have divided social media according to the level of consumer openness and the media interactivity level. For example, a lot of private information is shared on social networks, but the level of interactivity is lower than in the virtual social worlds. Agnihotri et al. (2017) point that social media have a large impact on the sales process because of the opportunity of maintaining a connection with their clients. Newly performed research shows empirically-based proof that social media makes relations with clients better. Companies that have integrated social media into maintaining relations with their clients have shown better and more satisfying products and services. In this way, they receive better acclaim from their clients (Agnihotri et al., 2017). Andzulis et al. (2012) also emphasize that integration of social media within companies has to be considered as a dynamic, constantly changing process. It is a part of a marketing strategy that has to be constantly monitored and changed. Social media is a strategic tool that quickly evolves and changes.

It is important to note that when companies began to invest into social media as a primal sales channel, it became significant to see how this sales process differs from the traditional sales process, for example, scientists have already researched the eye movements and attention points within a «Facebook» clothing shop context. Results of this research have shown that salespeople can catch the customer's attention by manipulating the presented price position and location (Menon et al., 2016). It was indicated that both men and women concentrate much more on the price of the product if it comes together with the product's picture. The respondents have paid less attention to prices that were positioned next to company information and the «like» button (Menon et al., 2016). Individuals agree to pay a larger price for products, which in their opinion are more valuable and solve the problem in a better way than the other alternatives in the market. Zheng et al. (2017) research have shown that consumers' opinion towards a product or service in the context of value depends on the communication of the business subject and the information that they spread on social media. Effective communication in social media can improve consumer attitudes towards quality by also influencing the opinion towards the added value of the offered object or service. Moreover, information that describes a good quality product or service increases the effectiveness of consumer decision making. For this reason, the company's information that is published in the social environment is extremely important (Sabaityte and Davidavicius, 2017). Companies have special offers and greater value for their social network followers as they are seeking to attract consumers (Deloitte, 2015). Interpersonal communication of the consumers and the information that they share about a specific product or service also influence the opinion towards the value (Davidaviciene et al., 2019b). Positive reviews, notes and experiences of other consumers create trust for the company and raise awareness towards value propositions (Zheng et al., 2017).

The consumers tend to buy from a familiar seller both in the physical and social environment (Davidaviciene et al., 2017). When trying to create and sustain influence on social networks, companies have to attract different consumer segments (Litterio et al., 2017). For this reason, promoting sales through opinion leaders is becoming a more popular choice than digital advertising (Rum, 2018). As Vaughan (2016) claims, a survey made in the United States of America has shown that $70 \%$ of generation $Y$ consumers are influenced by other people's opinions during a sales process. Social networks have 
become key environments where consumers share their feelings and ideas. Individuals with internet influence often have a high number of followers that are united by certain characteristics. The follower base is a concentrated target audience. Popular opinion leaders attract followers by creating and sharing content online. By posting pictures, their thoughts and immersive blog and video content they have received the interest and trust of their followers. Influential people use the opportunities of digital communication and quickly reach their target audience by recommending goods or services in a digital environment (Litterio et al., 2017). Research grounds the fact that members of generation $Y$ rarely evaluate their choices on their own. Family, friends and social media have an immense impact on their decisions (Viswanathan and Jain, 2013).

When evaluating the specifics of generation Y, Goward (2018) presents LIFT (Landing Page Influence Function for Tests) conversion optimization model which consists of 6 parts that allow analysing the effectiveness of an internet page from the perspective of the consumer (Goward, 2018):

- Value proposition - the main and most important factor that influences the consumer.

- Relevance - the presented information has to be important for the consumer.

- Clarity - is the main obstacle that the marketing specialists are confronted with. All marketing information has to be easily understandable. Consumer buys goods and services that are understandable for them. Clients have to understand the presented content and know the actions that they have to perform in order to purchase a product. The value proposition has to be clearly formulated and the encouragement to purchase the products has to be used properly.

- Anxiety - it is a probable concern that a consumer may have before making the purchase. The consumer has to feel safe.

- Urgency - it is a hint for the consumer that they need to take action. Urgency consists of two parts: internal urgency - how the consumer feels before being presented with the value proposition; external urgency - how the marketing information encourages the consumer to take action.

- Distraction - it is necessary to eliminate all elements that are not related to the marketing message. Excess information confuses the consumer. It is advised to systemize information, group it, present it in a form that is easier to comprehend. Consumers tend to choose simple solutions that solve their existing problems.

All possible internal, external and philosophical problems can be solved by properly leading the customer in the sales process. The consumers tend to make simple choices that solve their existing problems, that implies why there should be less and less distracting elements in the sales process. People tend to buy products and services that they understand. Creating stories is a powerful tool that helps systemize complex information that is understandable for the consumer. Famous companies emphasize the simplicity of the products that they create. Product design and the user interface is clear to the consumer. The product that is created and sold has to be described and explained to the consumer. A clear and understandable marketing message must convince the consumer that if they buy the product or service, their life will become better. Often times, people buy not the best products but the ones that they understand. Content marketing engages the consumer by communicating in a way that is clear to them. Blogs, videos and other visual content that is created is a great way to interest the consumer and help solve their problems (Rum, 2018).

Methodology and research methods. Case study and survey methods have been chosen to identify factors that decide upon generation Y's social media engagement. This method gives an opportunity to closely analyse and describe one event or fact in a real context and identify the researched phenomenon, especially when the borders between a phenomenon and its context are not clear, and, later on, to clarify the conclusions by using the survey results.

The research object - factors that determine generation $Y$ engagement with social media. The purpose of the research - to define the determining factors of generation $Y$ engagement. 
To reach the goal of this research these tasks were created: to identify the opportunities of social media utilization in the sales process and to indicate the factors that influence generation $Y$ consumer engagement.

Video content was created and posted on Youtube to evaluate the effectiveness of social media tools. The channel shares information about transport vehicles, their maintenance, repairs and other related topics.

The interaction of generation $Y$ and social media was examined in the first stage of the research. Video material was created to indicate the possible social media use in the sales process. The first video was uploaded on the private Youtube channel on 04-09-2017. Research results were summarized since the first video upload until 30-08-2018. There were created 12 video recordings, from which 7 videos created until 22-12-2017 had no scientifically recommended principles towards generation $Y$ and 5 videos created from 13-01-2018 had integrated scientifically recommended solutions. Data has been received from a personal Youtube account. The information was collected by connecting to the constantly renewed Youtube Analytics database.

During this research «Value proposition», «Motives for engagement», "Viewers specific» and «Opportunity to use social media in the sales process» were evaluated.

In the second part of the research, an online survey of generation $Y$ consumers has been conducted to evaluate the relevance of the identified factors. The survey was active from $12^{\text {th }}$ June to $17^{\text {th }}$ December 2018. 359 people participated in the survey, 271 of which were members of generation $Y$, born in between 1981-2000.

Results. «Value proposition» on Youtube platform. Content created for Youtube is oriented towards solving consumer problems. The published material is about how to fix your transport vehicle and save money. The viewer is given ideas and information on how they can make their situation better by fixing their car. Videos created up until 22-12-2017 have only that one principle. These videos only have information placed in them, there were no relations created with the viewers. The videos did not have a visible human face, there was no direct contact. It was noticed that visitor involvement during this time was low. The videos would receive a few hundred views. Videos only had a few comments. The number of subscribers was growing slowly. From creating the channel in 22-12-2017 the number of subscribers grew up to 100 only.

Motives for engagement. From 13-01-2018 communication principles were started to apply in the videos. Video content had direct contact with the viewers, showing their face, using informal language that is typical for generation Y. After performing a keyword search, it became clear that most searches are without Lithuanian characters, the phrases used are not always correct. Properly selected keywords allow the videos to become visible in the search result pages. After applying these principles, the number of subscribers grew up to 2490 (Table 1).

Table 1. Comparison of viewer involvement

\begin{tabular}{|c|c|c|c|}
\hline \multirow{2}{*}{ Positions } & \multicolumn{3}{|c|}{ Date } \\
\cline { 2 - 4 } & Until 22-12-2017 & From 13-01-2018 & Until 22-12-2017 \\
\hline Number of videos & 7 & 5 & 7 \\
\hline Number of views & 51486 & 96636 & 51486 \\
\hline Positive feedback & 591 & 1117 & 591 \\
\hline Negative feedback & 29 & 147 & 29 \\
\hline Comments & 144 & 647 & 144 \\
\hline
\end{tabular}

Source: made by the authors.

Great interest shown by the viewers, comments and viewing time has led the video that was uploaded on 03-02-2018 to the most popular videos list in Lithuania on Youtube. This high position made the video 
even more popular with the viewers. The video was recommended to the visitors of the Lithuanian Youtube website.

Viewer specifics. It has been found out that out of 148588 views, more than $80 \%$ viewers of the channel are members of generation $Y$. The topic of cars attracts the interest of more male viewers. $96 \%$ of all the views were made by male viewers. Most of the views, $88.5 \%$, happened in Lithuania. Research results have shown that more videos were viewed on mobile devices (55\%) and computers (39\%).

Opportunity to use social media in the sales process. The videos uploaded on 13-01-2018 and 03-022018 had presented cars. The videos had clearly described the status of the car, its defects and other related information. All these details were presented in a simple language that is easily understood by the target consumer. Social media platforms were combined in the car sale process:

- transition encouragement to purchase the car was used on Youtube. The information about the product was presented in a playful way;

- direct encouragement to purchase was used on the Facebook platform. The advertisement for the car was posted and shared within the target car purchase/sales groups.

Moreover, car advertisements were shared on «Autoplius» advertisement portal, which is one of the most popular ones in Lithuania. The description of the advertisement had the same information and pictures as the Facebook advertisement. A standard way of contact was supplied - a phone number. There was a lively discussion on Facebook. People were sharing the link of the video on Youtube under the advertisement of the car. The posted content on social media has satisfied the LIFT model (Goward, 2018) conditions (Value proposition, Relevance, Clarity, Anxiety, and Urgency).

In «Autoplius», a classified automobile advertising portal, the advertisements attracted a few interested persons. These people have contacted the indicated phone number, but they did not show further interest in buying the car. Buyers of transport vehicles found the advertisement for this car on Facebook. After contacting through a personal message, they agreed upon a viewing time for the car. When they arrived, they already knew the state of the car because both buyers had already seen the videos on Youtube. The research confirmed the significance and necessity of combining different social media platforms because it allows the buyers to receive additional information, which makes the sales process faster. Generation $Y$ is used to buying things by using social media. It was noticed that social media can be a more effective sales channel rather than traditional car advertising on the Internet. Important to note that it is vital to combine certain communication principles to encourage generation $Y$ involvement. Only by offering value consumer involvement is lower than when integrating product history and direct digital communication.

After performing additional research (a survey), the opinion of the respondents confirmed the conclusions of the first research. All of the people who participated in this research responded that they have used social media websites within the last 24 months. This question can be considered as the control one as the survey was posted on social media websites. Moreover, $96.7 \%$ of the respondents think that information posted on social media (i.e. Youtube, Facebook, Instagram, etc.) influences the decision to buy something. Besides, the relevance of the researched topic is justified by the result that $91.9 \%$ of respondents have personally purchased something on the internet within the last 24 months. Those who responded have said that the reasons to shop on the internet are the best available price $(21.07 \%)$, discounts $(17.9 \%)$ and the delivery of the goods to their home or a delivery point (17.03\%).

It is obvious from the results that generation $Y$ members mostly value the benefits of a lower price, which is received when shopping online. The respondents indicated social networks (30\%) and internet shops $(23.3 \%)$ as the most acceptable media that strengthen the popularity of certain goods or an e-shop. The answers to this question ground the fact that the information that is shared on social media about company offers is acceptable to the respondents. Consumers find the offers by browsing on social media. 
Additionally, the information that is published on the internet shop website is acceptable for the respondents.

During respondents' product/service search on the Internet the decision to buy is mostly determined by having discounts $(13.7 \%)$, a large variety of choice $(12.4 \%)$, and a comfortable search $(11.4 \%)$.

After analysing the results, it is possible to see the connection with the result of the next question when the respondents indicated the reasons why they shop on the Internet. The choice to shop on the Internet is determined by lower prices and the feeling of safety $(9.3 \%)$. Important to note that the choice to buy is also determined by recommendations and advice by other persons (9.8\%). Respondents were asked to indicate whether they agree or disagree with given statements (in a scale from 1 to 10 , where 1 meant complete disagreement with the statement and 10 - complete agreement). Concrete evaluations of each statement were established after performing a statistical analysis. It shows that for the consumers the value proposition is extremely important. The average of the responses is 8.96 . The response mode is 10 .

The second most important statement is that respondents take into account others' opinions, comments and reviews on the Internet. That shows how important are feedback and the word of mouth for passing information. The average of responses is 8.16 . The response mode is 10 . This high response rate shows that comments, opinions and experiences posted on social media are an important factor for generation $Y$ consumers when they choose products.

It is important for generation $Y$ that a product would match their style. An opportunity to receive a personalized product or service is often appealing to the consumers of generation $Y$. The response average is 7.82. Response mode is 10. It shows that it is important for generation $Y$ consumers to match the product or service according to their needs. A need for personalization is observed. Generation $Y$ consumers value the ability to customize a product according to their taste or needs. The average of this response reaches 7.34 . Interestingly, the response averages and response modes are low when talking about messages that products communicate about someone's personality and opinion leaders, and their influence to purchase something (Table 2).

Table 2. Analysis of statements evaluated in a Likert scale

\begin{tabular}{|c|c|c|}
\hline Question & Mode & Average \\
\hline I consider opinion leaders' comments on the Internet when buying a product & 5 & 5.42 \\
\hline $\begin{array}{c}\text { I consider what kind of a message will this object communicate about me when choosing } \\
\text { a product }\end{array}$ & 1 & 5.81 \\
\hline
\end{tabular}

Source: made by the authors.

It can be assumed that the Lithuanian consumers of generation $Y$ that participated in the survey lack openness, they do not want to admit the importance of these factors or they are not that important. These discrepancies could be an opportunity for further research to find out about the influence of opinion leaders and the message that a product communicates about one's personality towards the decision to buy for generation $\mathrm{Y}$ consumers.

The respondents search for the best price and discounts when choosing goods on the Internet. For them, it is important to have a wide range of choice and the comfort of ordering goods on the Internet or when picking them up. Brand awareness and company image are considered. The offered item has to be appealing to the consumer, to reflect their style, point of view. The survey has confirmed the opinion that the best way to reach generation $Y$ consumers is by using social media.

Model. Analysing the specifics of generation $Y$ is a constant process as the members of this generation are becoming the main participants in the contemporary market. Companies that are trying to survive and thrive must grasp the needs of one of the largest population groups. The decision-making process to buy products or services of generation $Y$ consumers is extremely complicated. The literature review and performed research show the complexity of the situation. It has been identified that traditional models of 
encouragement to buy something are not working on generation $Y$ consumers. It has been observed that the majority of these consumers tend to shop on the Internet. The specifics of generation $Y$ and their personal features determine very different ways of deciding to make purchases. Constantly and quickly developing technologies influence the development of social media as well. The way of a Generation $Y$ consumer making a choice to buy something can be long and tricky with endless elements that influence them. The variety of social media determines that every consumer has a unique experience and expectations. Due to constantly changing specifics of social media and ways of presenting information it would not be purposeful to focus only on one social media channel, i.e. Facebook, Instagram or other. An effective way to communicate with generation $Y$ needs to be discovered. They need to be interested, their attention has to be captured and presented with a valuable proposition that these consumers would be happy with the choice that they have made so that they would purchase products and services and become clients that repeatedly return to buy. Model of social media factors that influence the decision to buy in generation $Y$ consumers (Figure 1) was formed on the basis of scientific research, an experimental case study and survey results.

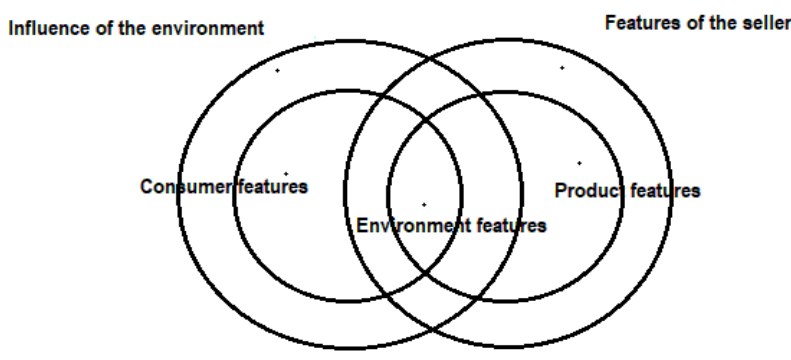

\section{Figure 1. Model of social media factors that influence the decision to buy in generation $Y$ consumers}

The core in the inner part of the model shows the decision-making process to buy of a Generation $Y$ consumer. The process consists of the emergence of a need, information search, a value proposition, decision, action and continuance. This chain of actions is connected by an arrow showing a cyclical sequence.

The actions pictured in the outer part of the model influence generation $Y$ decisions and the action of buying. The arrows in the outer part show that every group of factors can influence a generation $Y$ consumer in any stage of the purchase process. It is advised to consider these factors that influence consumer decisions when social media content is being created (Table 3).

Table 3. Factors influencing generation $Y$ consumers' decision to buy

\begin{tabular}{|c|c|}
\hline Factor group & Main factors \\
\hline $\begin{array}{c}\text { Features of the } \\
\text { seller/middleman }\end{array}$ & $\begin{array}{r}\text { Quality, privacy and safety control, reputation, delivery, service, interactivity, value } \\
\text { proposition, message of the brand name, prices, discounts. }\end{array}$ \\
\hline Consumer features & $\begin{array}{r}\text { Lifestyle, motivation, knowledge, innovation, hobbies, demographic features, style, } \\
\text { experience, expectations, attitude, self-expression. }\end{array}$ \\
\hline Product features & $\begin{array}{c}\text { Knowledge about the product, product type, packaging, price, functionality, identifying } \\
\text { with the product, simplicity. }\end{array}$ \\
\hline $\begin{array}{c}\text { Environment features } \\
\text { Influence of the } \\
\text { environment }\end{array}$ & $\begin{array}{c}\text { Website design, navigation, ease of use, trustworthines, safety, easy shopping process. } \\
\text { influence of media, attention, image, the possibility to digitalize, opinion leaders, } \\
\text { comments, advice. }\end{array}$ \\
\hline
\end{tabular}

Source: made by the authors. 
Due to generation $Y$ lifestyle and complex contemporary environment, it is not possible to claim that these factors are the only ones influencing the decision to buy. However, the performed analysis allows to conclude that the interest of generation $Y$ consumers will be higher when these aspects are considered when producing content for social media.

Conclusions. A model was created of factors that influence the decision to buy in generation $Y$ consumers in the context of social media based on the performed research. Social media can be one of the ways to attract generation $Y$ consumers and encourage them to perform the act of buying. It is perceived that each step of social media integration in the sales process for generation $Y$ consumers is directly related with the model of the factors that influence the decision to buy in generation $Y$ consumers in the context of social media. The model was applied when analysing an example in real environment. It was noticed that following the model attracts generation $Y$ consumers. After interesting them and giving a value proposition, the consumer performs a more in-depth information research, makes the decision and potentially performs the act of purchasing the product. Maintaining relations, creating a community and a relation is an extremely important step. Consumers of generation $Y$ constantly share their experience with others. Social media becomes an integral part of life that helps reach generation $Y$ consumers. The model that was created is meant for marketing specialists trying to attract the attention of generation $Y$ consumers. The model shows different stages of generation $Y$ consumer decision making process and the entirety of the factors that influence their decision to buy. It is important to emphasize the value proposition when creating social media content for generation $Y$ consumers. Only by properly leading the customer in the decision-making process to buy it is shown how a product or a service will solve the customer's problem. It is important in the long term that actual value would be created and relations with the customers would be managed in a close and positive manner. Further research could analyse generation $Z$ behaviour and the application of the elements of the model and structure for this generation as some generation $Z$ members are already becoming active participants in the market.

Author Contributions: Author contribution to the article was as following: methodology V. D. and R. P.; resources V. D. I. M. K and R. P; investigation R. P; analysis V. D. and I.M.K; writing-original draft preparation I. M. K. and R. P; writing-review and editing V. D.; visualization I. M. K.; supervision V. D.

\section{References}

Adnan, A., Ahmad, A., and Khan, M. N. (2017). Examining the role of consumer lifestyles on ecological behavior among young Indian consumers, Young Consumers, 18(4), 348-377. doi.org/10.1108/YC-05-2017-00699

Agnihotri, R., Trainor, K. J., Itani O. S., and Rodriguez, M. (2017). Examining the Role of Sales-Based CRM Technology and Social Media Use on Post-Sale Service Behaviors in India, Journal of Business Research, 81, 144-154. doi.org/10.1016/j.jbusres.2017.08.021

Alavijeh, M. R. K., Esmaeili, A., Sepahvand, A., and Davidaviciene, V. (2018). The Effect of Customer Equity Drivers on Wordof-Mouth Behavior with Mediating Role of Customer Loyalty and Purchase Intention, Inžinerine Ekonomika-Engineering Economics, 29(2), 236-246.

Andzulis, J. M., Panagopoulos N. G., and Rapp A. (2012). A Review of Social Media and Implications for the Sales Process, Journal of Personal Selling and Sales Management, 32 (3), 305-316. doi.org/10.2753/PSS0885-3134320302

Augustin, B. S. (2013). Understanding and Managing the Gen Y, Gen X, Baby Boomers and Traditionalists in Your Organization: Access through internet: https://docuri.com/download/understanding-and-managing-the-gen-y-gen-x-baby-boomers-andtraditionalists-in-your-organization 59c1e8aaf581710b286cbfof pdf

Bolton, R. N., Parasuraman, A. Hoefnagels, A., Migchels, N., Kabadayi, S., Gruber, T., Loureiro, Y. K., and Solnet,D. (2013). Understanding Generation $Y$ and their use of social media: a review and research agenda, Journal of Service Management, 24(3), 245-267. doi.org/10.1108/09564231311326987

Chami, B. (2013). Cultural Analysis of Factors affecting customers' online shopping behavior in Finland and Morocco. University of Oulu. Master thesis. Access through internet: http://jultika.oulu.fi/files/nbnfioulu-201311261929.pdf

Chan, G., Cheung, C., Kwong, T., Limayem, M., and Zhu, L. (2003). Online consumer behavior: a review and agenda for future research, 16th Bled eCommerce Conference eTransformation Bled, Slovenia, 194-218. Access through internet: http://aisel.aisnet.org/cgi/viewcontent.cgi?article=1112\&context=bled2003 
V. Davidaviciene, I. Meidute-Kavaliauskiene, R. Paliulis. Research on the Influence of Social Media on Generation Y Consumer Purchase Decisions

Dange, U., and Kumar, V. (2012). A Study of Factors Affecting Online Buying Behavior: A Conceptual Model, SSRN Social Journal, 1(1), 1-11.

Davidaviciene, V., Raudeliuniene, J., and Viršilaite, R. (2019a). User experience evaluation and creativity stimulation with augmented reality mobile applications, Creativity studies, 12(1), 34-48. doi: 10.3846/cs.2019.3576.

Davidaviciene, V., Raudeliuniene, J., Tvaronaviciene, M., and Kaušinis, J. (2019b). The importance of security aspects in consumer preferences in social environment, Journal of security and sustainability issues, 8(3), 399-411. doi: 10.9770/jssi.2019.8.3(9).

Davidaviciene, V., Pabedinskaite, A. O., and Davidavicius, S. (2017). Social networks in B2B and B2C Communication, Transformations in business and economics, 16(1), 69-84.

Deloitte (2015). Navigating the new digital divide, p. 22. Access through internet https://www2.deloitte.com/content/dam/Deloitte/us/Documents/consumer-business/us-cb-navigating-the-new-digital-divide-

051315.pdf

Goward, C. (2018). The LIFT Model: Use these six factors to increase your conversion rate. Wider funnel. Access through internet: https://www.widerfunnel.com/the-six-landing-page-conversion-rate-factors/

Jain, N. K., Kamboj, S., Kumar, V., and Rahman, Z. (2018). Examining consumerbrand relationships on social media platforms, Marketing Intelligence \& Planning, 36, 63-78. doi.org/10.1108/MIP-05-2017-0088

Kane S. (2017). Common Characteristics of Generation Y Professionals. The balance. Access through internet: https://www.thebalance.com/common-characteristics-of-generation-y-professionals-2164683

Kaplan, A. M, and Haenlein M. (2010). Users of the World, Unite! The Challenges and Opportunities of Social Media, Business Horizons 53 (1), 59-68. doi.org/10.1016/j.bushor.2009.09.003

Kemp, E. A., Borders, A. L., Anaza, N. A., and Johnston, W. J. (2018). The heart in organizational buying: marketers understanding of emotions and decision-making of buyers, Journal of Business \& Industrial Marketing, 33(1), 19-28. doi.org/10.1108/JBIM-06-2017-0129

Kemp, S. (2018). Digital in 2018. We are social. Access through internet: < https://wearesocial.com/uk/blog/2018/01/globaldigital-report-2018>

Lavidge, R. J., and Steiner, G. R. (1961). A Model for Predictive Measurements of Advertising Effectiveness. Access through internet: https://www.ama.org/academics/Documents/Lavidge-Steiner-Model.pdf

Liao, S. H., and Chung, Y. C. (2011). The effects of psychological factors on online consumer behavior. Graduate Institute of Management Sciences, Access through internet: https://www.researchgate.net/publication/241626159_The_effects_of psychological_factors_on_online_consumer_behavior

Litterio, A. M., Nantes, E. A., Larrosa J. M., and Gómez L. J. (2017). Marketing and Social Networks: A Criterion for Detecting Opinion Leaders, European Journal of Management and Business Economics, 26(3), 347-366. doi.org/10.1108/EJMBE-10-2017020

Mayfield, A. (2008). What is Social Media? Access through internet: http://www.icrossing.com/uk/sites/defaultfiles_uk/insight_ pdf_files/What\%20is\%20Social\%20Media_iCrossing_ebook.pdf

Menon, R. G. V., Sigurdsson, V., Larsen, N. M., Fagerstrøm, A. and Foxall, G. R. (2016). Consumer Attention to Price in Social Commerce: Eye Tracking Patterns in Retail Clothing, Journal of Business Research, 69 (11), 5008-5013. doi.org/10.1016/j.jbusres.2016.04.072

Nash, J. (2018). Exploring how social media platforms influence fashion consumer decisions in the UK retail sector, Journal of Fashion Marketing and Management: An International Journal, 23(1), 82-103. doi.org/10.1108/JFMM-01-2018-0012.

Raudeliuniene, J., Davidaviciene, V., Tvaronaviciene, M., and Jonuška, L. (2018). Evaluation of advertising campaigns on social media networks, Sustainability, 10(4), 1-14. doi: 10.3390/su10040973.

Raudeliuniene, J., and Davidavicius S. (2017). A conceptual model of assessment of knowledge transfer to consumer, Business, Management and Education, 15(2), 174-195. doi: https://doi.org/10.3846/bme.2017.387

Rum, J. (2018). 18 Digital Strategy Tips to Consider for 2018, Social Media Today. Access through internet: https://www.socialmediatoday.com/news/18-digital-strategy-tips-to-consider-for-2018/513807/

Sabaityte J., and Davidavicius S. (2017). Challenges and solutions of adopting public social services for the needs of Z generation, International journal of learning and change, 9(1), 17-28. doi.org/10.1504/IJLC.2017.084242

Silveira, M. P., Cardoso, M. V., and Quevedo-Silva, F., (2018). Factors influencing attendance at stadiums and arenas, Marketing Intelligence \& Planning, 37 (1), 50-65. doi.org/10.1108/MIP-02-2018-0048

Valentine, D., B., and Powers, T. L. (2013). Generation Y values and lifestyle segments, Journal of Consumer Marketing, 30(7), 597 - 606. doi:http: //dx.doi.org/10.1108/JCM-07-2013-0650

Vaughan, C. (2016). Influencer Marketing Update: Non-Celebrity Influencers 10 Times More Likely to Drive In-Store Purchases. Access through internet: https://collectivebias.com/blog/2016/03/non-celebrity-influencers-drive-store-purchases/

Viswanathan, V., and Jain, V. (2013). A dual-system approach to understanding generation $Y$ decision making, Journal of Consumer Marketing, 30(6), 484-492. doi.org/10.1108/JCM-07-2013-0649 53.

Williams, K. C. and Page, S. R. A. (2011). Marketing to the Generations, Journal of Behavioral Studies in Business, 3(1), 37 - 
V. Davidaviciene, I. Meidute-Kavaliauskiene, R. Paliulis. Research on the Influence of Social Media on Generation Y Consumer Purchase Decisions

Zheng, C., Yu, X. and Jin, Q. (2017). How User Relationships Affect User Perceived Value Propositions of Enterprises on Social Commerce Platforms, Information Systems Frontiers, 19(6), 1261-1271. doi.org/10.1007/s10796-017-9766-y

Zhong, Q., Liang, S., Cui, L., Chan, H.K. and Qiu, Y. (2018). Using online reviews to explore consumer purchasing behaviour in different cultural settings, Kybernetes, 48(6), 1242-1263. doi.org/10.1108/K-03-2018-0117

Biда Давідавічієне, Ph.D., профессор, Вільнюський технічний університет імені Гедимінаса (Литва);

Ієва Мейдут-Каваліаускієне, Ph.D., доцент, Вільнюський технічний університет імені Гедимінаса (Литва);

Регімантас Паліуліс, Вільнюський технічний університет імені Гедимінаса (Литва).

Дослідження впливу соціальних медіа на поведінку споживачів покоління $Y$

Ця стаття узагальнює аргументи та контраргументи в межах наукової дискусії з питання впливу соціальних медіа на поведінку споживачів покоління Ү. Систематизація літературних джерел та підходів до вивчення поведінки споживачів засвідчила, що в умовах розвитку інфрормаційних технологій та соціальних мереж суттєвих змін зазнають соціальні процеси у споживчій поведінці людей, особливо ие стосується покоління Ү. Актуальність вирішення даної наукової проблеми полягає в тому, що купівельний процес та споживча поведінка покоління Үзалежить від зміни у сучасному світі, які впливають на звички та особливості суспільства, цінності та потреби людей. Авторами наголошено, що одним із основних каналів спілкування покоління $Y \in$ соціальні мережі. Основною метою проведеного дослідження $є$ вивчення особливостей поведінки споживачів покоління Y та впливу соціальних медіа на їх рішення щодо придбання товарів або послуг. Дослідження питання впливу соціальних медіа на поведінку споживачів покоління Үв статті здійснено в наступній логічній послідовності: створення контенту на Үoutube каналі для оцінки еффективності інструментів соціальних медіа; встановлення фокторів, які визначають залучення покоління Y до соціальних медіа; проведення онлайн-опитування споживачів покоління Ү для оцінки відповідності виявлених фракторів. Контент Youtube каналу складається з інфоормації про транспортні засоби, їх обслуговування, ремонт та інші пов'язані теми. Методичним інструментарісм встановлення факторів, які визначають причини залучення покоління $Y$ до соціальних медіа стали метод кейсів та опитування. До процесу опитування було залучено 359 осіб, 271 з яких були предсавниками покоління Ү, народжених у період 1981-2000 роки, періодом дослідження обрано термін з 12 червня по 17 грудня 2018 року. Результати проведеного дослідження дозволили авторам виділити основні маркетингові фактори, що впливають на рішення споживача, оцінено їх вплив на купівельний процес споживачів покоління $Y$.

Ключові слова: електронний маркетинг, е-маркетинг, маркетинг, модель, соціальні медіа, технології.

Manuscript received: 27.09.2019.

(C) The author(s) 2019. This article is published with open access at Sumy State University. 